\title{
Six-year mortality in a street-recruited cohort of homeless youth in San Francisco, California
}

Colette L Auerswald, Jessica S Lin, Andrea Parriott

Objectives. The mortality rate of a street-recruited homeless youth cohort in the United States has not yet been reported. We examined the six-year mortality rate for a cohort of street youth recruited from San Francisco street venues in 2004. Methods. Using data collected from a longitudinal, venue-based sample of street youth 15-24 years of age, we calculated age, race, and gender-adjusted mortality rates. Results. Of a sample of 218 participants, 11 died from enrollment in 2004 to December 31, 2010. The majority of deaths were due to suicide and/or substance abuse. The death rate was 9.6 deaths per hundred thousand person-years. The age, race and gender-adjusted standardized mortality ratio was 10.6 (95\% confidence interval: 5.3 - 18.9). Gender specific SMRs were 16.1 (95\% Cl: 3.3 - 47.1) for females and 9.4 (95\% Cl: 4.0 - 18.4) for males. Conclusions. Street-recruited homeless youth in San Francisco experience a mortality rate in excess of ten times that of the state's general youth population. Services and programs, particularly housing, mental health and substance abuse interventions, are urgently needed to prevent premature mortality in this vulnerable population. 
2

3

4

5

6

\section{Six-Year Mortality in a Street-Recruited Cohort of Homeless Youth in San Francisco, California}

11

2

3

(1) University of California Berkeley-University of California San Francisco Joint Medical Program, School of Public Health, University of California Berkeley;

Berkeley, California, USA

(2) School of Public Health, University of California Berkeley; Berkeley, California, USA

(3) Philip R. Lee Institute for Health Policy Studies, University of California San Francisco; San Francisco, California, USA 


\section{ABSTRACT}

23

24 Objectives. The mortality rate of a street-recruited homeless youth cohort in the United States

25 has not yet been reported. We examined the six-year mortality rate for a cohort of street youth

26 recruited from San Francisco street venues in 2004.

27 Methods. Using data collected from a longitudinal, venue-based sample of street youth 15-24

28 years of age, we calculated age, race, and gender-adjusted mortality rates.

29 Results. Of a sample of 218 participants, 11 died from enrollment in 2004 to December 31, 2010.

30 The majority of deaths were due to suicide and/or substance abuse. The death rate was 9.6 deaths

31 per hundred thousand person-years. The age, race and gender-adjusted standardized mortality

32 ratio was 10.6 (95\% confidence interval: $5.3-18.9)$. Gender specific SMRs were 16.1 (95\% CI:

$333.3-47.1)$ for females and 9.4 (95\% CI: 4.0 - 18.4) for males.

34 Conclusions. Street-recruited homeless youth in San Francisco experience a mortality rate in 35 excess of ten times that of the state's general youth population. Services and programs, 36 particularly housing, mental health and substance abuse interventions, are urgently needed to 37 prevent premature mortality in this vulnerable population. 


\section{INTRODUCTION}

39

40

41

42

43

44

45

46

47

48

49

50

51

52

53

54

55

56

57

Homeless youth experience a disproportionate risk for morbidity, including, but not limited to, HIV and other sexually transmitted infections, Hepatitis B and C, and psychiatric disorders. ${ }^{1-7}$ Homeless adults have been shown to experience increased mortality. ${ }^{8-21}$ This elevated risk of mortality may be especially high amongst homeless youth. Table 1 summarizes the existing published findings regarding street youth mortality rates and standardized mortality rates in Europe, North America, and Australia. Of the studies that have examined rates of mortality among adult homeless populations, eleven have presented data for a youth subgroup within the sample. ${ }^{8-12,15-19,21}$ Of those reporting age- and gender-specific standardized mortality ratios (SMR), youth SMRs ranged from 2.1 to 37.32, generally higher than the SMRs found amongst older participants in the same studies. ${ }^{8-12,15,16,22,23}$

[Insert Table 1 here]

Of note, a census-based study of life expectancies in Canada found that a 25-year old male living in shelters, rooming houses, or hotels had a $32 \%$ chance of surviving to the age of 75 , as compared to $51 \%$ of housed males living in the lowest fifth income bracket. ${ }^{24}$ A national registry-based study of homeless persons in Denmark found that the remaining life expectancy for individuals who first accessed shelter between the ages of 15-24 was 38.7 years for men and 47.4 years for women, compared to 60.3 and 64.8 years respectively for the general population of Danish men and women. ${ }^{18}$ Investigators in Montreal have focused specifically on street youth, conducting two five-year prospective cohort studies with youth initially recruited from service agencies at ages 14-25.22,23,25 Roy and colleagues found an SMR of 15.3 in their first cohort tracked from 1995-2000, and a subsequent 79\% mortality rate decrease to an SMR of 3.0 in their 
60 second cohort tracked from 2001-2006, attributed to an improvement in local services to help the

61 homeless and injection drug using populations.

62 Though the United States and Canada are geographically and economically similar, the

63 national health care system and broader social safety net in Canada offers a substantially

64 different context and resources for youth homelessness in the two countries. Thus, mortality rates

65 found in Canada may not be comparable to those in the US. Of the four existing US-based

66 studies that presented youth-specific mortality data, three were conducted prior to 2000 . All four

67 were retrospective studies of homeless adults including youth over the ages of 15 or 18 , whose

68 names were collected from shelter or service utilization records. ${ }^{12,15-17}$

A limitation of all of the studies listed in Table 1 is the use of convenience samples

recruited from service providers, such as shelters and clinics. A challenge to recruiting street

71 youth is that they are less likely to access services than homeless adults, making service-based

72 sampling less likely to be representative of a homeless youth population than for adults. Our

73 prior research suggests this may be particularly true of homeless African American youth, who

74 were far less likely to access services for homeless youth than were their white counterparts. ${ }^{26}$

75 Similarly, we found in another study that homeless youth recruited during street outreach had

76 higher rates of high-risk sexual and drug-related behaviors than youth recruited from local clinics

77 for homeless youth. ${ }^{27}$ Given the challenges to recruiting members of a hard-to-reach population

78 that cannot be enumerated using conventional methods, other approaches, including venue-based

79 sampling, have been proposed to recruit a purposive sample. ${ }^{28-33}$

80 We undertook the current study to assess the standardized mortality ratios for a six-year

81 prospective cohort of homeless youth recruited entirely from street sites, using venue-based

82 sampling in San Francisco in 2004. 


\section{METHODS}

84 85

The Street Youth in Social Environments (Street Y-SE) study was a longitudinal study which examined the relationships among street culture, social networks and STI/HIV risk in San Francisco homeless youth. Recruitment, sampling, and study methods have been previously described. ${ }^{26,34}$ We employed venue-based sampling, a method of accessing both service-engaged and non-engaged hard-to-reach populations, such as homeless youth, by recruiting them at the venues where they spend time (for example, street corners or parks). ${ }^{28-33}$ Prior to enrollment, we conducted a mixed qualitative-quantitative assessment of venues to inform the selection of our recruitment sites. Based on street observations and ethnographic interviews with homeless youth, providers and outreach workers, a list of 62 preliminary venues was compiled. Brief street interviews were subsequently conducted at each venue to characterize the volume and composition of the youth population at each site. Based on these findings, the final list of venues was narrowed to 28 , based on gender composition, number of youth and redundancy. Our approach to venue selection was adapted from a prior study. ${ }^{28,29}$

Because youth are often intermittently homeless, eligibility was limited to youth who were 15 to 24 years of age and who had experienced unstable housing in the prior six months, defined as "having to stay two nights or more in a place that is not your home because you could not stay in your home or you did not have a home, including having to stay in one of the following places: a shelter, outdoors, a squat, with a stranger or someone you did not know well, a car, on public transportation, or SRO/hotel." Exclusion criteria included being actively under the influence of alcohol or illicit substances, or being too distressed or agitated to participate in the interview. Youth provided written informed consent for their participation. 

time of enrollment. Interviews were conducted in English. Gender (male, female, or

107 transgender), race/ethnicity, and age were self-reported. Youth were allowed to report up to six 108 racial categories (Black/African American, White/European American, Native 109 American/Alaskan, Latino/Hispanic, Pacific Islander/Polynesian, Asian/Asian-American, 110 Mixed) or "Don’t Know" or "Refuse.” Interviews also recorded information regarding

111 characteristics such as youth's housing history, service or health care utilization, sexual and 112 substance use patterns, education, and experiences while on the street. ${ }^{26,34}$

113 Deaths were tracked via the National Death Index (NDI), a nationwide index of death 114 certificate data through the end of 2010. Causes of death were determined by NDI-Plus. Methods 115 for identifying a match are described in detail on the NDI website 116 (http://www.cdc.gov/nchs/ndi.htm). The index was queried and matches were made using legal 117 names, aliases, dates of birth, and Social Security numbers, as reported by study participants.

118 Follow-up time began on the date of enrollment into the study, and ended either at death or on 119 December 31, 2010.

120 To calculate a standardized mortality ratio, youth were divided into 32 strata based on 121 age (15 to 24 or 25 to 34 years old), sex (male or female, as no street-recruited youth identified 122 as transgender) and race/ethnicity. We employed these age strata as they are those employed in

123 the reporting of California mortality rates. ${ }^{35}$ For this analysis, all persons who reported more than 124 one racial category or chose "mixed" as their primary racial identity were classified as "two or 125 more races" and all persons who reported "don't know" or "refuse" or left the race/ethnicity 126 question blank were considered to be of "unknown" race or ethnicity. As there were no 127 Asian/Asian American youth in our sample, only seven race/ethnicity categories were included. 
128 For stratum-specific comparison mortality rates, we used the mean mortality rate for California

129 for the years 2004 through $2010 .{ }^{35}$ For the four strata of youth of unknown race/ethnicity, we

130 employed the overall California youth population of the same age and sex as our reference

131 population for the SMR. SAS version 9.3 was used to calculate stratum specific follow-up time,

132 and expected deaths were calculated using Excel. The SMR and Fisher's exact 95\% confidence

133 intervals were calculated using OpenEpi version 3.03. ${ }^{36}$

134 We examined the bivariate relationship of demographic and behavioral variables to

135 mortality using Fischer's 2-sided exact test.

136 The protocol was approved by the Committee for Human Subjects of the University of

137 California at San Francisco (Study Number 11-05254).

138

\section{RESULTS}

Our street-recruited sample included 218 youth. One hundred and forty three $(65.6 \%)$

141 were male and $75(34.4 \%)$ were female. The mean sample age at baseline was 20.5 years, with a

142 standard deviation of 2.1 years. The sample was $50.5 \%$ non-Latino/white, $14.7 \%$ non-Latino

143 Black, 26.6\% multi-racial, 2.8\% Native American, 1.4\% Latino, $0.9 \%$ Pacific Islander, and

$1443.2 \%$ unknown.

145 The cohort accrued a total of 1,150.8 years of follow-up. There were a total of 11 deaths

146 for a death rate of 9.6 deaths per thousand person-years of follow-up. Of the 11 deaths, 8 were

147 male and 3 were female; 8 were non-Latino/Hispanic white and 3 were of mixed race. The age,

148 race, and sex standardized mortality ratio for the entire sample was $10.6(95 \%$ confidence

149 interval: 5.3 - 18.9). The gender specific SMRs were 16.1 (95\% CI: $3.3-47.1)$ for females and 1509.4 (95\% CI: $4.0-18.4)$ for males. 
154 deaths were suicides and/or alcohol- or drug-related. Our definition of alcohol- or drug-related

Table 3 summarizes the demographics and behavioral characteristics of the decedents and survivors. No demographic or behavioral factor had a statistically significant (Fisher's 2-sided exact $\mathrm{p}<0.05)$ or marginally significant $(\mathrm{p}<0.1)$ association with mortality. However, there was a trend towards an association with injection drug use (IDU) with $63.6 \%$ of decedents vs. $36.2 \%$ of survivors having had a history of IDU $(\mathrm{p}=.11) .{ }^{38}$

\section{DISCUSSION} excess of ten times that of the state's general youth population. The primary causes of death in our cohort were suicide and/or alcohol- or drug-related, similar to those observed in some previous studies. ${ }^{8,23,39}$

Although the standardized mortality ratio we found was higher than relative mortality measures from previous US studies that relied on service based sampling ${ }^{12,15,16}$, these SMRs are not directly comparable. As these studies were not all standardized to the same population, differences between effect measures may occur due to differences in the demographic profiles of

171 the study samples, in addition to differences in the stratum specific relative risks of mortality. mean excess risk of mortality than the males. However, all previous studies calculating gender 
174 specific SMRs but one (where there were no female decedents) have reported a higher point

175 estimate for the SMR for females than for males. ${ }^{9,11,16,23,39}$

176 Our study adds to the literature in several ways. To our knowledge this is the first

177 prospective cohort study of the mortality of street youth in the United States, and furthermore,

178 the only such mortality study to have recruited participants entirely through street-based venues,

179 rather than service or shelter-based sampling. Our findings are thus more likely to reflect the risk

180 of mortality of a youth found in a street setting versus a youth who has already accessed services.

181 A third strength of our study is that we adjusted our SMRs for age, race and sex, unlike most

182 prior studies which have been simply age and sex-adjusted. Given the recognized disparities in

183 US mortality by race/ethnicity, this is an important addition to current analyses. ${ }^{40}$

184 The limitations of our study should be considered. Though venue-based sampling

185 allows for a more representative sample of participants than samples recruited through

186 service providers, it remains a non-random sample with limited generalizability. The

187 English language requirement for interview participation may have excluded potential

188 Spanish-speaking or other monolingual participants, impacting the representativeness of

189 this study. However, the venues where we recruited youth were generally not venues

190 frequented by street-based monolingual Spanish-speaking youth, who tend to congregate

191 in neighborhoods distinct from the neighborhoods where the Y-SE study was conducted.

The exclusion of youth under the influence of substances or exhibiting emotional distress

193 or agitation at the point of recruitment may have excluded youth with a higher propensity toward

194 substance abuse or serious mental health issues, thus potentially underestimating deaths.

195 However, we recorded only one youth who was excluded for this reason (due to persistent 196 psychosis). 
198 the homeless. ${ }^{41}$ Thus, although half of the reported deaths occurred outside of California, the 199 experiences and rate of mortality experienced by our participants may not be generalizable to 200 homeless youth from elsewhere in the United States.

201 Furthermore, we may have missed cases of deaths through incomplete or incorrect 202 identifying information for participants, deaths outside of the United States, or deaths that were 203 not captured in the NDI. However as undercounting deaths in the cohort would lead us to 204 underestimate mortality rates for homeless youth, any bias would be towards the null. Finally, 205 because we were only able to adjust for age, race, and gender, there is possibility of confounding 206 in our SMR estimate.

Though it is not a limitation, a cautionary note is indicated here. The SMRs that we report 208 should not be directly compared to those in the table, nor should the SMRs in the table be 209 compared to each other without a clear understanding that the referring group is different for 210 each of the papers. Thus, we can only state that youth in each location had a higher or lower 211 mortality rate, relative to its own referent population, not to each other's rate. Despite these limitations, our findings hold important potential policy implications, 213 particularly given the federal commitment to ending youth homelessness by $2020 .{ }^{42}$ While our 214 results, and the results of previous studies, do not conclusively prove that youth homelessness 215 causes excess mortality, it does seem reasonable to assume that homelessness among youth is an 216 indicator of high mortality risk. Even if the association between homelessness and mortality is 217 not causal, the high mortality rate in this cohort of young homeless men and women is a stark 218 reminder that interventions to reduce premature death in street youth are needed. Studies of 
219 adults have suggested that providing long-term housing decreases mortality. ${ }^{17}$ Provision of

220 housing is likely to be life-saving for youth as well.

221 Although rates of IDU were higher among decedents (63.6\%) than among those who

222 survived (36.2\%), IDU was not significantly associated with mortality $(\mathrm{p}=.11)$. However, we did

223 not have enough outcomes to definitively determine or refute this relationship. Additional data

224 would be necessary to definitively determine a causal relationship between IDU and the

225 increased risk of death among street-recruited homeless youth. Nevertheless, the high rate of

226 IDU among decedents is consistent with prior findings of a high rate of mortality among

227 injection-drug using youth in San Francisco. ${ }^{39}$ Our findings support the development of mental

228 health, harm reduction, and other substance use interventions tailored to street youth as a public

229 health priority for this population. ${ }^{43}$ Roy and colleagues in Montreal have suggested that the drop

230 in mortality rates among their cohorts may have been due in part to new services for homeless

231 youth implemented during this time, particularly suicide-prevention services. ${ }^{22}$

232 Further research is warranted to explore the predictors of mortality among youth, in

233 particular the reasons why females may have a higher SMR than males. Should a gender

234 difference prove to be significant, this may reflect differences in the effect of the street social

235 environment on the health of males versus females. ${ }^{44,45}$ Such information may help inform the

236 development of appropriate, sub-group specific services for this group of highly marginalized,

237 highly vulnerable youth. Given that these youth come disproportionately from groups for which

238 society has a fiduciary responsibility, including survivors of physical and sexual abuse, foster

239 youth and youth with a history of involvement in the juvenile justice system, our collective

240 mandate to address their disparity in mortality is even more pressing. 
241 1. DeMatteo D, Major C, Block B, Coates R, Fearon M, Goldberg E, King SM, Millson M,

242

243

244

245

246

247

248

249

250

251

252

253

254

255

256

257

258

259

260

261

262

263

264

265

266

267

268

269

270

271

272

273

274

275

276

277

278

279

280

281

282

283

284

285 O'Shaughnessy M, Read SE. Toronto street youth and HIV/AIDS: prevalence, demographics, and risks. J Adolesc Health. Nov 1999;25(5):358-366.

2. Ensign J, Gittelsohn J. Health and access to care: perspectives of homeless youth in Baltimore City, U.S.A. Soc Sci Med. Dec 1998;47(12):2087-2099.

3. Hahn JA, Page-Shafer K, Lum PJ, Ochoa K, Moss AR. Hepatitis C virus infection and needle exchange use among young injection drug users in San Francisco. Hepatology. Jul 2001;34(1):180-187.

4. Kennedy MR. Homeless and runaway youth mental health issues: no access to the system. J Adolesc Health. Nov 1991;12(7):576-579.

5. Larkin Steet Youth Services. Youth homelessness in San Francisco: 2013 report on incidence and needs. San Francisco, CA: Larkin Steet Youth Services;2014.

6. Noell J, Rohde P, Ochs L, Yovanoff P, Alter MJ, Schmid S, Bullard J, Black C. Incidence and prevalence of chlamydia, herpes, and viral hepatitis in a homeless adolescent population. Sex Transm Dis. Jan 2001;28(1):4-10.

7. Roy E, Haley N, Lemire N, Boivin JF, Leclerc P, Vincelette J. Hepatitis B virus infection among street youths in Montreal. Cmaj. Sep 21 1999;161(6):689-693.

8. Hwang SW. Mortality among men using homeless shelters in Toronto, Ontario. JAMA. Apr 26 2000;283(16):2152-2157.

9. Nordentoft M, Wandall-Holm N. Ten-year follow-up study of mortality among users of hostels for homeless people in Copenhagen. BMJ. Jul 12 2003;327(7406):81.

10. Alstrom CH, Lindelius R, Salum I. Mortality among homeless men. Br J Addict Alcohol Other Drugs. Sep 1975;70(3):245-252.

11. Babidge NC, Buhrich N, Butler T. Mortality among homeless people with schizophrenia in Sydney, Australia: a 10-year follow-up. Acta Psychiatr Scand. Feb 2001;103(2):105110.

12. Barrow SM, Herman DB, Cordova P, Struening EL. Mortality among homeless shelter residents in New York City. Am J Public Health. Apr 1999;89(4):529-534.

13. Beijer U, Andreasson S, Agren G, Fugelstad A. Mortality and causes of death among homeless women and men in Stockholm. Scand J Public Health. Mar 2011;39(2):121127.

14. Cheung AM, Hwang SW. Risk of death among homeless women: a cohort study and review of the literature. CMAJ. Apr 13 2004;170(8):1243-1247.

15. Hibbs JR, Benner L, Klugman L, Spencer R, Macchia I, Mellinger A, Fife DK. Mortality in a cohort of homeless adults in Philadelphia. N Engl J Med. Aug 4 1994;331(5):304309.

16. Hwang SW, Orav EJ, O'Connell JJ, Lebow JM, Brennan TA. Causes of death in homeless adults in Boston. Ann Intern Med. Apr 15 1997;126(8):625-628.

17. Metraux S, Eng N, Bainbridge J, Culhane DP. The impact of shelter use and housing placement on mortality hazard for unaccompanied adults and adults in family households entering New York City shelters: 1990-2002. J Urban Health. Dec 2011;88(6):10911104.

18. Nielsen SF, Hjorthoj CR, Erlangsen A, Nordentoft M. Psychiatric disorders and mortality among people in homeless shelters in Denmark: a nationwide register-based cohort study. Lancet. Jun 25 2011;377(9784):2205-2214. 
286 19. Shaw M, Dorling D. Mortality among street youth in the UK. Lancet. Aug 29

287

288

289

290

291

292

293

294

295

296

297

298

299

300

301

302

303

304

305

306

307

308

309

310

311

312

313

314

315

316

317

318

319

320

321

322

323

324

325

326

327

328

329

330 1998;352(9129):743.

20. Baggett TP, Hwang SW, O'Connell JJ, Porneala BC, Stringfellow EJ, Orav EJ, Singer DE, Rigotti NA. Mortality among homeless adults in Boston: shifts in causes of death over a 15-year period. JAMA. Feb 11 2013;173(3):189-195.

21. Nusselder WJ, Slockers MT, Krol L, Slockers CT, Looman CW, van Beeck EF. Mortality and life expectancy in homeless men and women in Rotterdam: 2001-2010. PLoS One. 2013;8(10):e73979.

22. Roy E, Haley N, Boudreau JF, Leclerc P, Boivin JF. The challenge of understanding mortality changes among street youth. Journal of Urban Health. Jan 2010;87(1):95-101.

23. Roy E, Haley N, Leclerc P, Sochanski B, Boudreau JF, Boivin JF. Mortality in a cohort of street youth in Montreal. JAMA. Aug 4 2004;292(5):569-574.

24. Hwang SW, Wilkins R, Tjepkema M, O'Campo PJ, Dunn JR. Mortality among residents of shelters, rooming houses, and hotels in Canada: 11 year follow-up study. BMJ. 2009;339:b4036.

25. Roy E, Boivin JF, Haley N, Lemire N. Mortality among street youth. Lancet. Jul 4 1998;352(9121):32.

26. Hickler B, Auerswald CL. The worlds of homeless white and African American youth in San Francisco, California: a cultural epidemiological comparison. Social Science and Medicine. Mar 2009;68(5):824-831.

27. Auerswald CL, Wilderson D, Sugano E, Schroeder A, Melendez E, Obata S, Scott K, Dowling T, Klausner J. Outreach-based STI testing accesses a higher-risk subgroup of homeless youth than clinic-based testing. Paper presented at the International Society for Sexually Transmitted Diseases Research Biannual Meeting, 2007.

28. Auerswald CL, Greene K, Minnis A, Doherty I, Ellen J, Padian N. Qualitative assessment of venues for purposive sampling of hard-to-reach youth: an illustration in a Latino community. Sex Transm Dis. Feb 2004;31(2):133-138.

29. Minnis A, Auerswald CL, Doherty I, Ellen J, Shiboski S, Padian N. Qualitative and quantitative methods for developing a venue-based sampling approach for a study of latino adolescents' social and sexual Networks. In: National Institute for Drug Abuse, ed. The Network Paradigm in Research on Drug Abuse, HIV, and Other Blood-Borne and Sexually Transmitted Infections. Bethesda, MD; 2002.

30. MacKellar D, Valleroy L, Karon J, Lemp G, Janssen R. The Young Men's Survey: methods for estimating HIV seroprevalence and risk factors among young men who have sex with men. Public Health Rep. 1996;111 Suppl 1:138-144.

31. Muhib FB, Lin LS, Stueve A, Miller RL, Ford WL, Johnson WD, Smith PJ, Community Intervention Trial for Youth Study Team. A venue-based method for sampling hard-toreach populations. Public Health Rep. 2001;116 Suppl 1:216-222.

32. Stueve A, O'Donnell LN, Duran R, San Doval A, Blome J. Time-space sampling in minority communities: results with young Latino men who have sex with men. American Journal of Public Health. 2001;91(6):922-926.

33. Kral A, Malekinejad M, Vaudrey J, Martinez A, Lorvick J, McFarland W, Raymond H. Comparing respondent-driven sampling and targeted sampling methods of recruiting injection drug users in San Francisco. Journal of Urban Health. 2010;87(5). 
331 34. Parriott AM, Auerswald CL. Incidence and predictors of onset of injection drug use in a

35. California Department of Public Health. Health information and strategic planning: State of California. 2012.

36. OpenEpi: Open Source Epidemiological Statistics for Public Health [computer program]. http://www.OpenEpi.com.

37. Kochanek KD, Xu J, Murphy SL, Minino AM, Kung HC. Deaths: final data for 2009. Natl Vital Stat Rep. Dec 29 2011;60(3):1-116.

38. Jepsen P, Johnsen SP, Gillman MW, Sørensen HT. Interpretation of observational studies. Heart. 2004;90:956-960.

39. Evans JL, Tsui JI, Hahn JA, Davidson PJ, Lum PJ, Page K. Mortality among young injection drug users in San Francisco: a 10-year follow-up of the UFO study. Am J Epidemiol. Feb 15 2012;175(4):302-308.

40. Mulye TP, Park MJ, Nelson CD, Adams SH, Irwin CE, Jr., Brindis CD. Trends in adolescent and young adult health in the United States. J Adolesc Health. Jul 2009;45(1):8-24.

41. Department of Housing and Urban Development. Fiscal Year 2014 Continuum of Care Competition Homeless Assistance Award Report. https://www.hudexchange.info/onecpd/assets/File/2014-california-coc-grants.pdf [accessed on March 3, 2016].

42. United States Interagency Council on Homelessness. Youth. http://usich.gov/population/youth [accessed on June 2nd, 2015].

43. Seal KH, Thawley R, Gee L, Bamberger J, Kral AH, Ciccarone D, Downing M, Edlin BR. Naloxone distribution and cardiopulmonary resuscitation training for injection drug users to prevent heroin overdose death: a pilot intervention study. J Urban Health. Jun 2005;82(2):303-311.

44. Bourgois P, Prince B, Moss A. The everyday violence of Hepatitis C among young women who inject drugs in San Francisco. Hum Organ. Sep 2004;63(3):253-264.

45. Valente AM, Auerswald CL. Gender differences in sexual risk and sexually transmitted infections correlate with gender differences in social networks among San Francisco homeless youth. $J$ Adolesc Health. Oct 2013;53(4):486-491. 


\section{Table $\mathbf{1}$ (on next page)}

Mortality rates, person-years of observation, and standardized mortality rates in published studies (or study subsets) of homeless youth.

Table 1: Mortality rates, person-years of observation, and standardized mortality rates in published studies (or study subsets) of homeless youth. 


\begin{tabular}{|c|c|c|c|c|c|c|}
\hline & \begin{tabular}{|l|} 
Age \\
range
\end{tabular} & Subject recruitment & $\begin{array}{l}\text { Follow Up } \\
\text { (years, } \\
\text { person } \\
\text { years) }\end{array}$ & $\begin{array}{l}\text { Mortality } \\
\text { rate } \\
\text { (per 1,000 } \\
\text { person- } \\
\text { years) }\end{array}$ & SMR (CI) & $\begin{array}{l}\text { Reference } \\
\text { Population }\end{array}$ \\
\hline \multicolumn{7}{|l|}{ United States } \\
\hline $\begin{array}{l}\text { Philadelphia } \\
\text { (Hibbs, } \\
1994)^{15}\end{array}$ & $15-34$ & $\begin{array}{l}\text { Shelter/service } \\
\text { record review }\end{array}$ & $3(12,481)$ & 6.03 & $\begin{array}{l}3.8(2.8- \\
5.7)^{\mathrm{a}}\end{array}$ & $\begin{array}{l}\text { Philadelphia } \\
\text { general } \\
\text { population }\end{array}$ \\
\hline $\begin{array}{l}\text { Boston } \\
(\text { Hwang, } \\
1997)^{16}\end{array}$ & $18-24$ & $\begin{array}{l}\text { Health care services } \\
\text { record review }\end{array}$ & 6 & $\begin{array}{l}\text { Males: } 5.34 \\
\text { Females: } \\
1.96\end{array}$ & $\begin{array}{l}\text { Males: } 5.9 \\
(2.1-17.0)^{\mathrm{a}} \\
\text { Females: } \\
11.8(4.2- \\
33.1)^{\mathrm{a}}\end{array}$ & $\begin{array}{l}\text { Boston general } \\
\text { population }\end{array}$ \\
\hline $\begin{array}{l}\text { New York } \\
\text { (Barrow, } \\
1999)^{12}\end{array}$ & $20-24$ & $\begin{array}{l}\text { Random recruitment } \\
\text { at shelters }\end{array}$ & 7 & $\begin{array}{l}\text { Males: } 6.85 \\
\text { Females: nc } \\
\text { deaths }\end{array}$ & $\begin{array}{l}\text { Males: } 4.2 \\
(0.4-11.9)^{\mathrm{a}} \\
\text { Females: no } \\
\text { deaths }\end{array}$ & US population \\
\hline $\begin{array}{l}\text { New York } \\
\text { (Metraux, } \\
2011)^{17}\end{array}$ & $20-24$ & Shelter record review & $\mid \begin{array}{l}\text { Mean: } 11.4 \\
(975,916)\end{array}$ & $\begin{array}{l}\text { Males: } 4.63 \\
\text { Females: } \\
2.87\end{array}$ & NR & \\
\hline \multicolumn{7}{|l|}{ Canada } \\
\hline $\begin{array}{l}\text { Toronto } \\
\text { (Hwang, } \\
2000)^{8}\end{array}$ & $18-24$ & Shelter record review & $2(22,958)$ & 4.21 & $\begin{array}{l}8.3(4.4- \\
15.6)^{d}\end{array}$ & $\begin{array}{l}\text { Toronto general } \\
\text { population }\end{array}$ \\
\hline $\begin{array}{l}\text { Montreal } \\
(\text { Roy, 2004) }\end{array}$ & $14-25$ & $\begin{array}{l}\text { Service-based } \\
\text { recruitment }\end{array}$ & $6(2,822)$ & 9.21 & \begin{tabular}{|l}
$11.4(7.4-$ \\
$16.7)^{\mathrm{e}}$ \\
Males: 11.1 \\
$(6.9-16.8)^{\mathrm{a}}$ \\
Females: \\
$13.5(3.6-$ \\
$34.5)^{\mathrm{a}}$ \\
\end{tabular} & $\begin{array}{l}\text { Quebec } \\
\text { province } \\
\text { general } \\
\text { population }\end{array}$ \\
\hline $\begin{array}{l}\text { Montreal } \\
(\text { Roy, 2010) }\end{array}$ & $14-25$ & $\begin{array}{l}\text { Service-based } \\
\text { recruitment }\end{array}$ & 5 & 1.9 & $\begin{array}{l}3.0(1.0- \\
6.9)^{\mathrm{e}}\end{array}$ & $\begin{array}{l}\text { Quebec } \\
\text { province } \\
\text { general } \\
\text { population } \\
\end{array}$ \\
\hline \multicolumn{7}{|l|}{ Europe } \\
\hline $\begin{array}{l}\text { Stockholm } \\
\text { (Alstrom, } \\
1975)^{10} \\
\end{array}$ & $20-29$ & $\begin{array}{l}\text { Social/temperance } \\
\text { aid service record } \\
\text { review }\end{array}$ & 3 & NR & $9.0^{\mathrm{d}}$ & $\begin{array}{l}\text { Stockholm male } \\
\text { population }\end{array}$ \\
\hline $\begin{array}{l}\text { London } \\
(\text { Shaw, 1998) }\end{array}$ & $16-29$ & Death records & NR & 40.1 & $\begin{array}{l}37.32 \\
(20.38- \\
62.63)^{\mathrm{e}}\end{array}$ & $\begin{array}{l}\text { England and } \\
\text { Wales male } \\
\text { population }\end{array}$ \\
\hline $\begin{array}{l}\text { Copenhagen } \\
\text { (Nordentoft, } \\
2003)^{9}\end{array}$ & $15-24$ & $\begin{array}{l}\text { Government record } \\
\text { review }\end{array}$ & 10 & NR & $\begin{array}{l}\text { Males: } 13.3^{\mathrm{a}} \\
\text { Females: } \\
28.5^{\mathrm{a}}\end{array}$ & $\begin{array}{l}\text { Copenhagen } \\
\text { general } \\
\text { populaiton }\end{array}$ \\
\hline
\end{tabular}




\begin{tabular}{|c|c|c|c|c|c|c|}
\hline $\begin{array}{l}\text { Rotterdam } \\
\text { (Nusselder, } \\
2013)^{21}\end{array}$ & $20-29$ & Service record review & $10(17,619)$ & $\begin{array}{l}\text { Males: } 9.11 \\
\text { Females: no } \\
\text { deaths }\end{array}$ & NR & $\begin{array}{l}\text { Rotterdam } \\
\text { general } \\
\text { population }\end{array}$ \\
\hline \multicolumn{7}{|l|}{ Australia } \\
\hline $\begin{array}{l}\text { Sydney } \\
\text { (Babidge, } \\
\text { 2008) }\end{array}$ & $20-29$ & $\begin{array}{l}\text { Shelter/psych service } \\
\text { record review }\end{array}$ & $\begin{array}{l}10 \text { (range: } 7- \\
11)\end{array}$ & NR & $\begin{array}{l}\text { Males: } 3.51 \\
(1.29-7.64)^{a} \\
\text { Females: } \\
16.67 \\
(0.42- \\
92.02)^{\mathrm{a}} \\
\end{array}$ & $\begin{array}{l}\text { New South } \\
\text { Wales general } \\
\text { population }\end{array}$ \\
\hline
\end{tabular}

2 age-adjusted; ${ }^{\mathrm{b}}$ Age, sex and race-adjusted; ${ }^{\mathrm{c}}$ Age and race-adjusted; ${ }^{\mathrm{d}}$ Age-adjusted, males only; ${ }^{\mathrm{e}}$ Age and 3 sex-adjusted 
Table 2 (on next page)

Characteristics of study cohort survivors and decedents

Table 2: Characteristics of study cohort survivors and decedents. 
1

\begin{tabular}{|c|c|c|}
\hline & $\begin{array}{l}\text { Survivors }(\mathrm{n}=207)^{* *} \\
\text { (n; \% of responses) }\end{array}$ & $\begin{array}{l}\text { Decedents }(\mathrm{n}=11)^{* *} \\
(\mathrm{n} ; \% \text { of responses) }\end{array}$ \\
\hline \multicolumn{3}{|l|}{ Gender* } \\
\hline Male & $135(65.2 \%)$ & $8(72.7 \%)$ \\
\hline Female & $72(34.8 \%)$ & $3(27.3 \%)$ \\
\hline \multicolumn{3}{|l|}{ Race/ethnicity } \\
\hline Non-Latino/Hispanic White & $102(49.3 \%)$ & $8(72.7 \%)$ \\
\hline Non-Latino/Hispanic Black & $32(15.5 \%)$ & 0 \\
\hline Native American/Alaskan & $6(2.9 \%)$ & 0 \\
\hline Latino/Hispanic & $3(1.4 \%)$ & 0 \\
\hline Pacific Islander/Polynesian & $2(1.0 \%)$ & 0 \\
\hline Asian/Asian American & 0 & 0 \\
\hline 2 or more races & $55(26.6 \%)$ & $3(27.3 \%)$ \\
\hline Unknown & $7(3.4 \%)$ & 0 \\
\hline \multicolumn{3}{|l|}{ Age at recruitment } \\
\hline $15-17$ & $19(9.2 \%)$ & 0 \\
\hline $18-20$ & $83(40.1 \%)$ & $4(36.4 \%)$ \\
\hline 21 or older & $105(50.7 \%)$ & $7(63.6 \%)$ \\
\hline \multicolumn{3}{|l|}{ Age at $1^{\text {st }}$ unstable housing } \\
\hline 14 or younger & $73(35.3 \%)$ & $6(54.5 \%)$ \\
\hline $15-17$ & $82(39.6 \%)$ & $4(36.4 \%)$ \\
\hline $18-20$ & $46(22.2 \%)$ & $1(9.1 \%)$ \\
\hline 21 or older & $6(2.9 \%)$ & 0 \\
\hline Any services in last $3 \mathrm{mo}$. & $122(58.9 \%)$ & $5(45.5 \%)$ \\
\hline Any healthcare in last $3 \mathrm{mo}$. & $63(30.4 \%)$ & $4(36.4 \%)$ \\
\hline Survival sex & $36(17.4 \%)$ & $2(18.2 \%)$ \\
\hline Ever injected drugs $* * *$ & $75(36.2 \%)$ & $7(63.6 \%)$ \\
\hline $\mathrm{MSM}^{* * * *}$ & $14(13.5 \%$ of males $)$ & $0(0 \%$ of males $)$ \\
\hline $\begin{array}{l}\text { High school graduate (only among } \\
\text { respondents }>18 \text { yo) }\end{array}$ & $109(52.7 \%)$ & $5(50.0 \%)$ \\
\hline
\end{tabular}

2

$3 * \quad$ None of the youth in the sample identified as transgender.

$4 * * \quad$ There were no statistical differences between the characteristics of survivors and

5 decedents at the $\mathrm{p}<.05$ or $\mathrm{p}<.1$ level.

6 *** $\mathrm{p}=.11$.

7 **** Though there were not missing data for other questions, there were missing data for

8 men reporting having sex with men (39/143). However, all male decedents responded. 
Table 3 (on next page)

Causes of death for cohort decedents

Table 3: Causes of death for cohort decedents. 


\begin{tabular}{|l|l|}
\hline ICD 10 Code & Description \\
\hline B20.8 & HIV disease resulting in other infectious and parasitic diseases \\
\hline F10.2 & $\begin{array}{l}\text { Mental and behavioral disorders due to use of alcohol (Dependence } \\
\text { syndrome) } \\
\text { Mental and behavioral disorders due to multiple-drug use and use } \\
\text { of other psychoactive substances (Harmful use) }\end{array}$ \\
\hline F19.1 & $\begin{array}{l}\text { Mental and behavioral disorders due to multiple-drug use and use } \\
\text { of other psychoactive substances (Dependence syndrome) }\end{array}$ \\
\hline F19.2 & Other ill-defined and unspecified causes of mortality \\
\hline R99 & $\begin{array}{l}\text { Inhalation and ingestion of other objects causing obstruction of } \\
\text { respiratory tract }\end{array}$ \\
\hline W80 & $\begin{array}{l}\text { Accidental poisoning by and exposure to other and unspecified } \\
\text { drugs, medicaments, and biological substances }\end{array}$ \\
\hline X44 & $\begin{array}{l}\text { Intentional self-poisoning (suicide) by and exposure to other and } \\
\text { unspecified drugs, medicaments, and biological substances }\end{array}$ \\
\hline X64 & $\begin{array}{l}\text { Intentional self harm (suicide) by other and unspecified firearm } \\
\text { damage }\end{array}$ \\
\hline X74 & $\begin{array}{l}\text { Intentional self harm (suicide) by jumping or lying before moving } \\
\text { object }\end{array}$ \\
\hline X81 & Assault (homicide) by other and unspecified firearm discharge \\
\hline X95 &
\end{tabular}

